Review

\title{
Applications of Aptasensors in Clinical Diagnostics
}

\section{Ping Hong ${ }^{1,2}$, Wenli $\mathrm{Li}^{1,2}$ and Jinming $\mathrm{Li}^{1,2, *}$}

1 National Center for Clinical Laboratories, Beijing Hospital, Beijing 100730, China;

E-Mails: pinghong98@yahoo.com (P.H.); totolwl@163.com (W.L.)

2 Graduate School, Peking Union Medical College, Chinese Academy of Medical Sciences, Beijing 100730, China

* Author to whom correspondence should be addressed; E-Mail: ljm63hn@yahoo.com.cn; Tel.: +86-10-5811-5053.

Received: 19 December 2011; in revised form: 11 January 2012 / Accepted: 29 January 2012 / Published: 30 January 2012

\begin{abstract}
Aptamers are artificial oligonucleotides (DNA or RNA) selected in vitro that bind a broad range of targets with high affinity and specificity; a sensitive yet simple method to utilize aptamers as recognition elements for the development of biosensors (aptasensors) is to transduce the signal electrochemically. So far, aptasensors have been applied to clinical diagnostics and several technologies are in development. Aptasensors will extend the limits of current clinical diagnostics. Although the potential diagnostic applications are unlimited, the most current applications are foreseen in the areas of biomarker detection, cancer clinical testing, detection of infectious microorganisms and viruses. This review attempts to list examples of the research progresses of aptamers in biosensor platforms that have been published in recent years; in particular, we display cases of aptasensors that are already incorporated in clinical diagnostics or have potential applications in clinical diagnostics.
\end{abstract}

Keywords: biosensor; aptamer; aptasensors; clinical diagnostics

\section{Introduction}

High requirements regarding human health have resulted in an increasing number of clinical tests, so there is a rising need to develop more sensitive, reliable, time-efficient and inexpensive methods of analysis. Conventional techniques, such as molecular assays (immunological 
or nucleic acid technologies) and microbial culture-based tests, are either time consuming or require sophisticated equipment and expensive. Biosensor technology is probably one of the fastest growing areas to solve some of the problems concerning sensitive, rapid and cheap measurement [1].

A biosensor is defined as a compact analytical device incorporating a molecular recognition entity associated with or integrated with a physicochemical transducer [2]. It consists of two main components, a biological component, which reacts with a target substance, and a signal-generating component, which detects the resulting products. More specifically, we can consider a biosensor as a type of biomolecular probe that weighs the presence or concentration of biological molecules or biological structures by translating a biochemical interaction at the probe surface into a quantifiable physical signal. Biosensors are already used for several clinical applications, such as for electrochemical measurement of blood glucose concentrations. The first generation of biosensors were catalytic systems that integrated particularly enzymes with transducers that transferred the biological reaction into an electronic signal. The next generation of biosensors, affinity biosensors, utilized different biological elements, such as antibodies, receptors (natural or synthetic). Furthermore, the reaction between the target and the immobilized biomolecule on the transduction element is controlled by affinity interactions, such as the antigen-antibody, the DNA-DNA.

Recognition molecules are the key element of biosensors since the sensitivity and specificity of the sensing elements will play an important role in the success of the sensor device [3]. A range of recognition molecules have been employed for clinical diagnosis. However, the use of antibodies in biosensor detection methods and in the analysis of very complex samples could partially be hampered by the nature and synthesis of these protein receptors. In order to circumvent some of these drawbacks, other recognition molecules, such as aptamers, are being explored as alternative. This review attempts to list examples of the research progress of aptamers in biosensor platforms that have been published in recent years; in particular, we display cases of aptasensors that are already incorporated in clinical diagnostics or have potential applications in clinical diagnostics.

\section{Aptasensors}

\subsection{Aptamers and Biosensors}

Aptamers (derived from the latin aptus, meaning to fit) are artificial nucleic acid (DNA or RNA) ligands which can be selected from combinatorial libraries of synthetic nucleic acids, possessing specific binding characteristics to their targets. Using the systematic evolution of ligands (SELEX) process, aptamers can be isolated from randomly synthesized RNA or DNA pools and produced. Numerous high-affinity and highly specific aptamers have been generated against a wide variety of target molecules including small organics, peptides, proteins, and even complex-target such as whole cell [4,5]. In addtion, aptamers can be selected against non-immunogenic and toxic targets, which make the technique superior to antibodies, enabling the design and synthesis of probes or capture molecules for such targets.

Biosensors that employ aptamers as a recognition element are called aptasensors [6]. DNA and RNA aptamers can be modified chemically to undergo analyte-dependent conformational changes. For instance, Aptamers can be modified for immobilization purposes and incorporated particular reporters, 
without influencing their affinity, which has aided varieties of design methods [7-12]. Aptamers can also be engineered to withstand repeated cycles of denaturation and renaturation; this opens up a possibility to regenerate the immobilized biocomponent function for reuse [6,13]. In addition, they can be easily labeled for their use in diagnostics [14].

\subsection{Signal-Transduction}

Development of aptasensors has been carried out with various detection schemes, from label-free methods, such as surface plasmon resonance (SPR) [15], and quartz crystal microbalance (QCM) measurements, to other methods often requiring labels, such as electrochemistry[16], fluorescence [17-19], chemiluminescence [20], field effect transistors [10,16], which have been reported and enhanced the advancement of this field. Alternatively, sensors often utilize labeled target molecules or secondary capture agents (in the case of a sandwich-type assay) which themselves contain some forms of label or reporter molecule. So far, there are mainly two types of aptasensors to apply, including electrochemical and optical aptasensors.

\subsubsection{Electrochemical Aptasensors}

A typical electrochemical aptasensor makes use of an electrode surface as the platform to immobilize biological sensing aptamer, for which the analyte-binding event is monitored based on electrochemical current variations. Electrochemical transduction offers the advantages of high sensitivity, which can be enhanced by attaching biocatalytic labels to the aptamer-target complexes to amplify the detection signal, readily miniaturized, and low cost of production since they do not require expensive optical instruments [16,21]. Additionally, it is possible to use label-free and reusable detection systems.

\subsubsection{Optical Aptasensors}

Optical aptasensors include aptamers labeled with fluorescence, luminophore, enzyme, nanoparticles) or aptamer with label-free detection systems (e.g., SPR, optical resonance) [22]. Most methods are mainly based on a labeling approach. Some targets can be optically detected using not only colorimetry, chemiluminescence or the most developed fluorescence mode but also more recent non-conventional optical methods such as surface plasmon-coupled directional emission (SPCDE) [22].

Different label-free techniques have recently been shown to be suitable for developing aptasensors or aptamer-based microarrays, such as surface plasmon resonance (SPR), diffraction grating, evanescent-field-coupled (EFC) waveguide-mode, optical resonance or Brewster angle straddle interferometry (BASI) [22]. SPR biosensors prepared using optical fibers can be used as a cost-effective and relatively simple-to-implement alternative to well established biosensor platforms for monitoring biomolecular interactions in situ or possibly in vivo [23].

\section{Application of Aptasensors in Clinical Diagnosis}

Beyond all these features, the applications of aptamers as bio-compotents have offered extraordinary prospects in diagnostic assays [24]. Here we briefly describe a few examples of the use of aptasensors in the areas of biomarker detection, cancer clinical testing, and detection of infectious microorganisms. 


\subsection{Application of Aptasensors for Detection of Biomarkers}

The analysis of biomarkers in blood, urine and other body fluids is one of the methods applied in the early detection of diseases. Aptasensors have been used for detection of biomarkers, such as thrombin, Immunoglobulin (Ig) E. A list of examples of the available reports of aptasensors for different biomarkers is provided in Table 1. Furthermore, representative examples of aptasensors for detection of thrombin are discussed in the following section.

Table 1. Examples of application of aptasensors for detection of biomarkers.

\begin{tabular}{|c|c|c|c|c|c|}
\hline $\begin{array}{c}\text { Target } \\
\text { biomarker }\end{array}$ & Aptamer & Detection type & $\begin{array}{c}\text { Signal } \\
\text { transduction }\end{array}$ & $\begin{array}{c}\text { Linear range/ } \\
\text { LOD }\end{array}$ & Reference \\
\hline Thrombin & $\begin{array}{l}\text { DNA labeled with the } \\
\text { HCoPt-RGs conjugates }\end{array}$ & Sandwich-type & Electrochemical & $\begin{array}{l}1.0 \times 10^{-12} \text { to } \\
5.0 \times 10^{-8} \mathrm{M} / \\
3.4 \times 10^{-13} \mathrm{M}\end{array}$ & $\begin{array}{l}\text { Wang et al. } \\
\text { (2011) [25] }\end{array}$ \\
\hline Thrombin & $\begin{array}{l}\text { DNA dual labeled with } \\
\text { AuNPs and HRP }\end{array}$ & Sandwich-type & Electrochemical & $\begin{array}{l}0.1 \text { to } 60 \mathrm{pM} / \\
30 \mathrm{fM}\end{array}$ & $\begin{array}{l}\text { Zhao et al. } \\
\text { (2011) [26] }\end{array}$ \\
\hline Thrombin & DNA & Label free detection & Fluorescence & $\begin{array}{c}0 \text { to } 0.02 \mu \mathrm{M} / \\
0.1 \mathrm{nM}\end{array}$ & $\begin{array}{l}\text { Pu et al. } \\
(2009)[27]\end{array}$ \\
\hline Thrombin & $\begin{array}{l}\text { DNA labeled with a } \\
\text { hole injector, } \\
\text { naphthalimide, and a } \\
\text { flurophore, Alexa532 }\end{array}$ & $\begin{array}{l}\text { DNA charge } \\
\text { transport }\end{array}$ & Fluorescence & $\begin{array}{c}5 \mathrm{pM} \text { to } 5 \mathrm{nM} / \\
1.2 \mathrm{pM}\end{array}$ & $\begin{array}{l}\text { Zhang et al. } \\
(2011) \text { [28] }\end{array}$ \\
\hline Thrombin & $\begin{array}{l}\text { DNA SA-ALP and } \\
\text { biotinylated labled }\end{array}$ & Sandwich-type & ECL & $\begin{array}{c}1 \times 10^{-15} \text { to } 1 \times 10^{-8} \mathrm{M} / \\
0.33 \mathrm{fM}\end{array}$ & $\begin{array}{l}\text { Liao et al. } \\
\text { (2011) [29] }\end{array}$ \\
\hline $\operatorname{IgE}$ & $\begin{array}{l}\text { DNA streptavidin } \\
\text { labled }\end{array}$ & ELISA-like array & SPR & $\begin{array}{l}\text { n.s./ } \\
\text { n.s. }\end{array}$ & $\begin{array}{l}\text { Wang et al. } \\
(2008)[30]\end{array}$ \\
\hline $\operatorname{IgE}$ & $\begin{array}{l}\text { DNA labeled with } \\
\text { avidin monolayer }\end{array}$ & Direct detection & $\begin{array}{c}\text { QCM } \\
\text { chemiluminescence }\end{array}$ & $\begin{array}{l}2.5 \text { to } 200 \mu \mathrm{g} \mathrm{L}^{-1} / \\
2.5 \mu \mathrm{g} \mathrm{L}^{-1}\end{array}$ & $\begin{array}{l}\text { Yao et al. } \\
(2009) \text { [31] }\end{array}$ \\
\hline $\operatorname{IgE}$ & $\begin{array}{l}\text { DNA labeled with } \\
\text { single PPy nanowire- } \\
\text { based microfluidic }\end{array}$ & $\begin{array}{c}\text { One step } \\
\text { electrochemical } \\
\text { deposition method }\end{array}$ & Electrochemical & $\begin{array}{c}0.1 \text { to } 100 \mathrm{nM} / \\
0.01 \mathrm{nM}\end{array}$ & $\begin{array}{l}\text { Huang et al. } \\
\text { (2011) [32] }\end{array}$ \\
\hline $\operatorname{IgE}$ & $\begin{array}{c}\text { DNA attached to } \\
\text { carboxyl (COOH)- } \\
\text { modified NCD surface }\end{array}$ & $\begin{array}{c}\text { Direct and } \\
\text { label-free detection }\end{array}$ & EIS & $\begin{array}{c}0.03 \text { to } 42.8 \mathrm{mug} / \mathrm{mL} / \\
0.03 \mathrm{mug} / \mathrm{mL}\end{array}$ & $\begin{array}{l}\text { Tran et al. } \\
\text { (2011) [33] }\end{array}$ \\
\hline RBP4 & single-stranded DNA & Label free detection & SPR & $\begin{array}{c}0.2 \text { to } 0.5 \mu \mathrm{g} \mathrm{mL}^{-1} / \\
75 \mathrm{nM}\end{array}$ & $\begin{array}{l}\text { Lee } \text { et al. } \\
(2008) \text { [34] }\end{array}$ \\
\hline CRP & RNA biotinylated & Direct detection & Optical & $\begin{array}{c}\text { n.s./ } \\
0.005 \mathrm{ppm}\end{array}$ & $\begin{array}{l}\text { Bini et al. } \\
(2008) \text { [35] }\end{array}$ \\
\hline CRP & DNA & Sandwich-type & Optical & $\begin{array}{c}10 \mathrm{microg} / \mathrm{L} \text { to } 100 \mathrm{mg} / \mathrm{L} / \\
\text { n.s. }\end{array}$ & $\begin{array}{l}\text { Pultar et al. } \\
(2009)[36]\end{array}$ \\
\hline NT-proBNP & $\begin{array}{c}\text { DNA with } \\
\text { cocaine-binding }\end{array}$ & Sandwich-type & ECL & $\begin{array}{l}0.01 \text { to } 500 \mathrm{ng} \mathrm{mL}^{-1} / \\
0.77 \mathrm{pg} \mathrm{mL}^{-1}\end{array}$ & $\begin{array}{l}\text { Mao et al. } \\
\text { (2011) [37] }\end{array}$ \\
\hline IFN gamma & $\begin{array}{l}\text { DNA thiolated/ } \\
\text { MB redox tag }\end{array}$ & Direct detection & Electrochemical & $\begin{array}{c}10 \mathrm{nM} / \\
0.06 \mathrm{nM}\end{array}$ & $\begin{array}{l}\text { Liu et al. } \\
\text { (2011) [38] }\end{array}$ \\
\hline
\end{tabular}

Abbreviations: LOD, limit of detection; HCoPt-RGs, hollow CoPt alloy nanoparticle onto reduced graphene oxide sheet; AuNP, Au nanoparticles; HRP, horseradish peroxidase; IgE, Immunoglobulin E; QCM, quartz crystal microbalance; SPR, surface plasmon resonance; PPy, polypyrrole ; EIS, Electrochemical impedance spectroscopy; NCD, nanocrystalline; RBP4, retinol binding protein 4; CRP, C-reactive protein; NT-proBNP, N-terminal pro-brain natriuretic peptide; ECL, electrochemiluminescence; MB, methylene blue; IFN, interferon; n.s., not specified. 
Thromin is an enzymatic active, circulating biomarker for blood coagulation activity levels. Clinical studies, applying assays and strategies applicable for endogenous plasma thrombin measurements, are needed to evaluate the clinical impact of thrombin. Nowadays, many assays, based on the thrombin-binding aptamer for the detection of thrombin, have been developed in recent years. Mostly, thrombin has been used as a model for detection in the aptasensors assays. The below are three cases.

An advanced sandwich-type electrochemical aptasensor assay coupled to use the hollow CoPt alloy nanoparticle $(\mathrm{HCoPt})-\mathrm{RGs}$ conjugates as secondary label demonstrated a good sensitivity and selectivity, with a limit of detection (LOD) of $3.4 \times 10^{-13} \mathrm{M}$. Scheme 1 illustrates the fabrication of electrochemical strategy with the aptamer-linked sandwich assay for the ultrasensitive detection of thrombin. The formed conjugates provided large surface area for loading plentiful redox probe thionine (Thi), horseradish peroxidase (HRP) and secondary aptamer (Apt II) with good stability and friendly biocompatibility [25].

Scheme 1. Schematic diagrams of preparation of the sandwich-type electrochemical aptasensor and TEM images of the hollow CoPt alloy nanoparticles decorated graphene. Reproduced with permission form Reference [25] (Abbreviations: HT, hexanethiol; GCE, glassy carbon electrode; CS-HCoPt, the chitosan-hollow CoPt alloy nanoparticle).
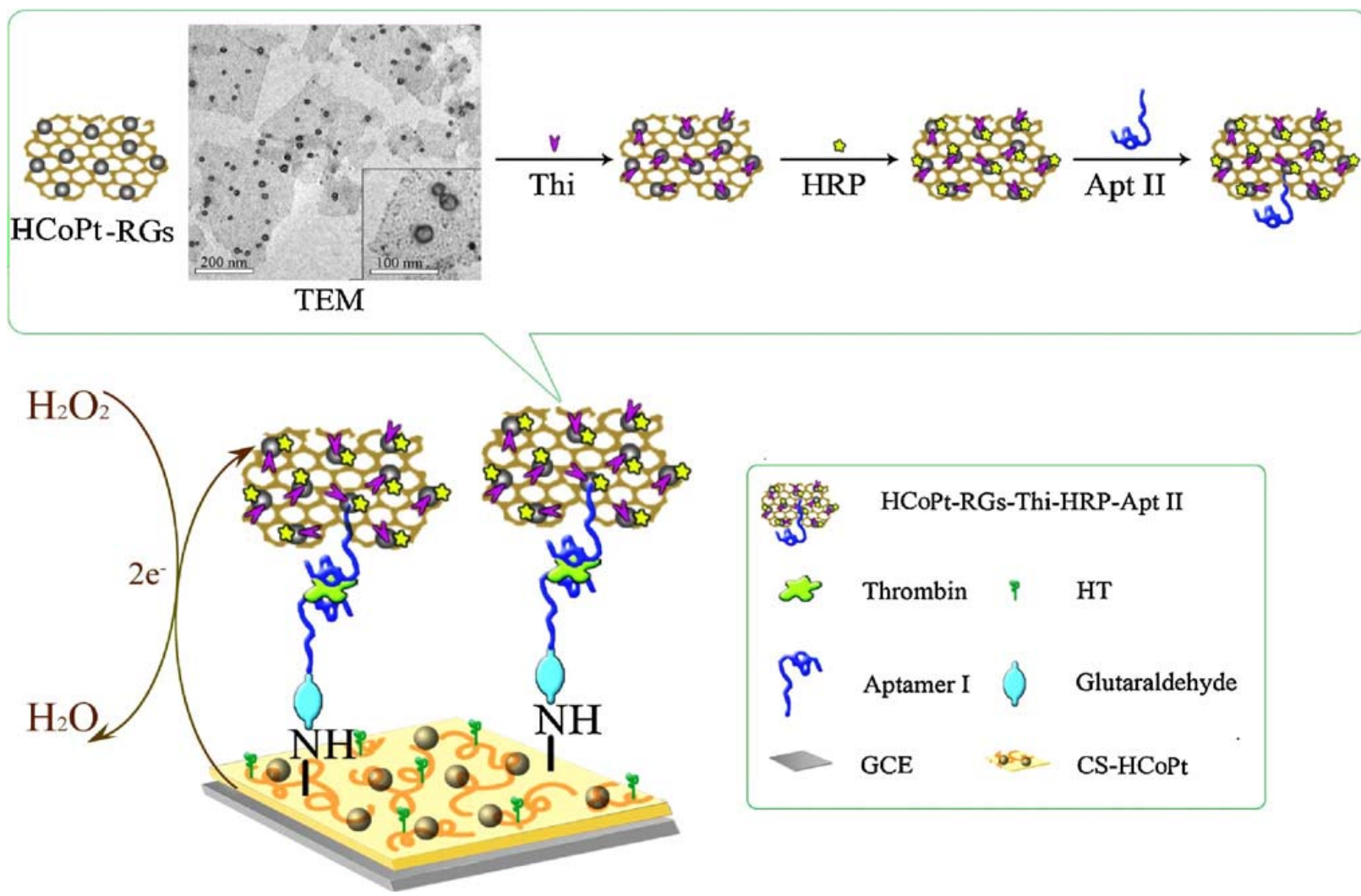

Also, a sandwich electrochemical aptasensor assay was developed for thrombin based on amplification of aptamer-gold nanoparticles-horseradish peroxidase (aptamer-AuNPs-HRP) conjugates [26]. In this electrochemical protocol, aptamer1 (Apt1) was immobilized on core/shell $\mathrm{Fe}_{3} \mathrm{O}_{4} / \mathrm{Au}$ magnetic nanoparticles (AuMNPs) and served as capture probe. Aptamer2 (Apt2) was dual labeled with AuNPs and HRP and used as detection probe. In the presence of thrombin, the sandwich format of AuMNPs-Apt1/thrombin/Apt2-AuNPs-HRP was fabricated. Remarkable signal amplification was realized by taking the advantage of AuNPs and catalytic reactions of HRP. Other proteins, such as 
human serum albumin, lysozyme, fibrinogen, and $\mathrm{IgG}$ did not show significant interference with the assay for thrombin. Linear response to thrombin concentration in the range of $0.1-60 \mathrm{pM}$ and the LOD of $30 \mathrm{fM}(\mathrm{S} / \mathrm{N}=3)$ was obtained with the proposed method. This electrochemical aptasensor was simple, rapid (the whole detection period for a thrombin sample is less than $35 \mathrm{~min}$ ), sensitive and highly specific, it showed promising potential in protein detection and disease diagnosis [26].

Meanwhile, aptasensor assays can be used for detection with various working principles. Pu et al. [27] have displayed a smart polymeric transducer and aptamer/intercalating dye system that allows the label-free detection of thrombin with high sensitivity and selectivity. Thrombin detection was completed through the simple "mix and detect" mode. In addition, the methodology didn't need any chemical modification on the probes or the analytes. The amount of the thrombin could be measured by the fluorescence intensity changes. The LOD was estimated to be $0.1 \mathrm{nM}$. This strategy might offer a new strategy to detect a wide spectrum of analytes and would be highly beneficial in future clinical applications.

\subsection{Application of Aptasensors for Cancer Clinical Testing}

With the growing number of cancer cases being diagnosed worldwide, cancer is the second most common cause of mortality and morbidity in the World due to late disease detection. Early diagnosis is crucial in all cancers to improve patient survival and disease prognosis, and may lead to cancer prevention- and for this reason sensitive and specific methods are required for early cancer diagnosis.

Detection and identification of tumor cells rely on the identification of some markers that appear only on the tumor cells such as lymphoma (Ramos) cells, leukemia cells. Identification of these cancer markers requires specific probes to bind in order to find the potential risk factor. In blood cells, plasma proteins or free DNA may be tumor markers. A number of recent studies have successfully used aptamers for targeting tumor markers.

Feng et al. [39] reported an example for label-free cancer cell detection by using an electrochemical sensor based on the first clinical oncology trial II used aptamer AS1411 and graphene-modified electrode. The aptamer-PTCA (perylenetetracarboxylic acid) nanocomposite was utilized as nanoscale anchorage substrates to effectively capture cells on electrode surface through the specific binding between cell surface nucleolin and the aptamer AS1411 (Scheme 2). The electrochemical aptasensor can distinguish cancer cells and normal ones and detect as low as one thousand cells. With DNA hybridization technique, this E-DNA sensor can be regenerated and reusable for cancer cell detection.

Platelet-derived growth factor B chain (PDGF-BB) is a potential cancer marker and is known to be related to tumor growth and transformation. Recently, Chai et al. [40] developed a sensitive and low cost ECL aptasensor for PDGF-BB by assembling N-(aminobutyl)-N-ethylisoluminol functionalized gold nanoparticles (ABEI-AuNPs) with aptamers as nanoprobes. The biotinylated aptamer capture probes were first immobilized on a streptavidin coated gold nanoparticle (AuNPs) modified electrode, then, a sandwich conjugate modified electrode was carried out by successively attached the target PDGF-BB and the ABEI-AuNPs tagged aptamer signal probe. ECL measurement was run with a double-step potential in carbonate buffer solution containing $\mathrm{H}_{2} \mathrm{O}_{2}$, showing high sensitivity and specificity. The detection limit was as low as $2.7 \times 10^{-14} \mathrm{M}$. In addition, the ABEI-AuNPs signal amplification was more simple, stable, practical, and sensitive compared to other reported signal 
amplification strategies based on aptamer-related polymerase chain reaction or functionalized nanoparticles. Moreover, 7 human serum samples were measured by using the proposed aptasensor. The obtained result were in good agreement those determined by the PDGF-BB ELISA as the reference method, which indicated that it was feasible to apply the proposed ECL aptasensor to detect PDGF-BB in real human serum samples. Table 2 lists examples of aptasensors for cancer clinical testing in recent years.

Scheme 2. Schematic representation of the reusable aptamer/graphene-based aptasensor. The sensor is constructed based on graphene-modified electrode and the first clinical trials II used aptamer, AS1411. AS1411 and its complementary DNA are used as a nanoscale anchorage substrate to capture/release cells. Reproduced with permission form Reference [39]. (Abbreviations: CCG, chemical converted grapheme; EDC, 1-ethyl-3-(3-dimethylaminopropyl) carbodiimide; NHS, N-hydroxysuccinimide).

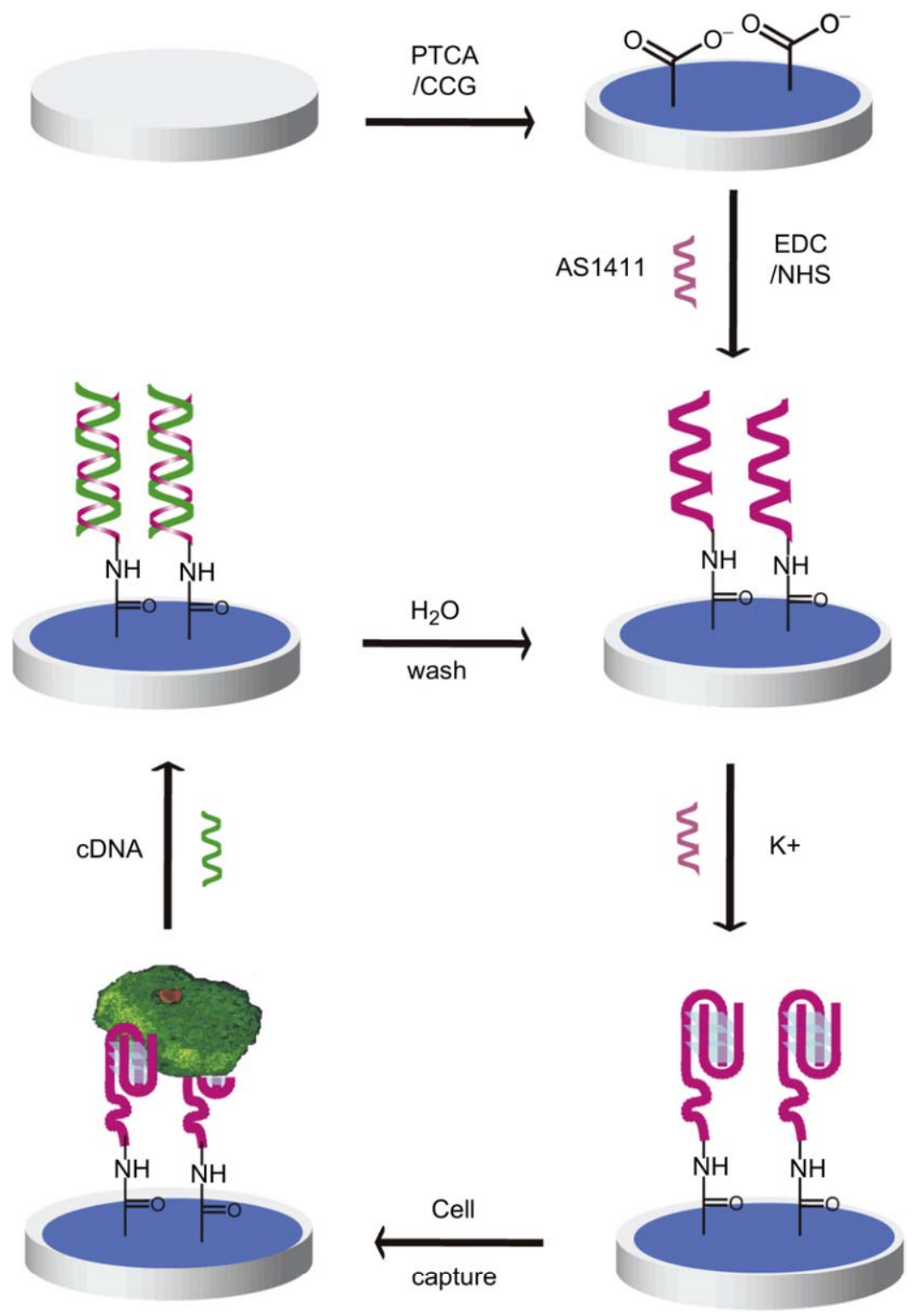


Table 2. Examples of application of aptasensors for cancer clinical testing.

\begin{tabular}{|c|c|c|c|c|c|}
\hline $\begin{array}{c}\text { Cancer marker } \\
\text { detected } \\
\end{array}$ & Aptamer & Detection type & Signal transduction & $\begin{array}{c}\text { Linear range/ } \\
\text { LOD }\end{array}$ & Reference \\
\hline $\begin{array}{l}\text { HeLa cells, K562 } \\
\text { cells, MDA- } 231 \text { cells }\end{array}$ & DNA & Label free detection & Electrochemical & $\begin{array}{l}\text { n.s./ } \\
\text { n.s. }\end{array}$ & $\begin{array}{l}\text { Feng et al. } \\
\text { (2011) [39] }\end{array}$ \\
\hline PDGF-BB & $\begin{array}{l}\text { DNA labeled } \\
\text { with biotin }\end{array}$ & $\begin{array}{l}\text { A sandwich conjugate } \\
\text { modified electrode }\end{array}$ & ECL & $\begin{array}{l}1.0 \times 10^{-13} \text { to } \\
1.0 \times 10^{-11} \mathrm{M} / \\
2.7 \times 10^{-14} \mathrm{M}\end{array}$ & $\begin{array}{l}\text { Chai et al. } \\
\text { (2011) [40] }\end{array}$ \\
\hline $\begin{array}{l}\text { Ramos cancer cell, } \\
\text { CEM cells }\end{array}$ & DNA & $\begin{array}{c}\text { ECL array with a novel } \\
\text { cycle-amplifying } \\
\text { technique }\end{array}$ & ECL & $\begin{array}{l}\text { n.s. } \\
\text { n.s. }\end{array}$ & $\begin{array}{l}\text { Jie } \text { et al. } \\
\text { (2011) [41] }\end{array}$ \\
\hline $\begin{array}{l}\text { Multi-marker or } \\
\text { Ramos cells, } \\
\text { CCRF-CEM cells, } \\
\text { Toledo Cells }\end{array}$ & $\begin{array}{l}\text { DNA-conjugated } \\
\text { FRET NP }\end{array}$ & $\begin{array}{l}\text { Simultaneous } \\
\text { multiplexed analysis }\end{array}$ & fluorescence & $\begin{array}{l}\text { n.s./ } \\
\text { n.s. }\end{array}$ & $\begin{array}{l}\text { Chen et al. } \\
(2009) \text { [42] }\end{array}$ \\
\hline Ramos cancer cell & DNA & Label free detection & ECL & $\begin{array}{l}100 \text { to } 1,000 \text { cells mL } \mathrm{m}^{-1} / \\
58 \text { cells } \mathrm{mL}^{-1}\end{array}$ & $\begin{array}{l}\text { Hun et al. } \\
\text { (2011) [43] }\end{array}$ \\
\hline Leukemia cells & $\begin{array}{c}\text { DNA conjugated } \\
\text { apt-MBs }\end{array}$ & $\begin{array}{l}\text { a magnet-quartz } \\
\text { crystal microbalance } \\
\text { system }\end{array}$ & QCM & $\begin{array}{c}1 \times 10^{4} \text { to } \\
1.5 \times 10^{5} \text { cells } \mathrm{mL}^{-1} / \\
8 \times 10^{3} \text { cells } \mathrm{mL}^{-1}\end{array}$ & $\begin{array}{l}\text { Pan et al. } \\
(2010) \text { [44] }\end{array}$ \\
\hline PSA & $\begin{array}{l}\text { DNA labeled } \\
\text { with FITC }\end{array}$ & $\begin{array}{c}\text { Aptamer blotting } \\
\text { assay }\end{array}$ & Chemiluminescence & $\begin{array}{l}40 \text { to } 100 \mathrm{nM} / \\
\text { n.s. }\end{array}$ & $\begin{array}{c}\text { Savory et al. } \\
2010[45]\end{array}$ \\
\hline MUC1 & $\begin{array}{l}\text { DNA labeled } \\
\text { with single PPy } \\
\text { nanowire-based } \\
\text { microfluidic }\end{array}$ & $\begin{array}{c}\text { One step } \\
\text { electrochemical } \\
\text { deposition method }\end{array}$ & Electrochemical & $\begin{array}{c}\text { n.s./ } \\
2.66 \mathrm{nM}\end{array}$ & $\begin{array}{l}\text { Huang et al. } \\
\text { (2011) [33] }\end{array}$ \\
\hline MUC1 & $\begin{array}{l}\text { DNA labeled } \\
\text { with QD }\end{array}$ & $\begin{array}{c}\text { Aptamer-based } \\
\text { detection with } \\
\text { quantum-dot based } \\
\text { fluorescence readout }\end{array}$ & Fluorescence & $\begin{array}{c}\text { n.s./ } \\
250 \mathrm{nM}\end{array}$ & $\begin{array}{l}\text { Cheng et al. } \\
\text { (2009) [46] }\end{array}$ \\
\hline GSH & RNA & $\begin{array}{l}\text { SPR analysis and } \\
\text { isocratic affinity } \\
\text { chromatography }\end{array}$ & SPR & $\begin{array}{l}\text { n.s./ } \\
\text { n.s. }\end{array}$ & $\begin{array}{l}\text { Bala et al. } \\
\text { (2011) [47] }\end{array}$ \\
\hline VEGF & $\begin{array}{l}\text { RNA conjugated } \\
\text { CPNTs }\end{array}$ & $\begin{array}{l}\text { FET-type biosensor } \\
\text { based on } \\
\text { CPNTs-aptamer }\end{array}$ & Electrochemical & $\begin{array}{c}\text { n.s./ } \\
400 \mathrm{fM}\end{array}$ & $\begin{array}{l}\text { Kwon et al. } \\
(2010)[48]\end{array}$ \\
\hline
\end{tabular}

Abbreviations: PDGF-BB, platelet-derived growth factor B chain; PSA, prostate specific antigen; MUC1, Mucin 1; FRET NP, fluorescence resonance energy transfer nanoparticles; GSH, Glutathione; SPR, surface plasmon resonance; ECL, electrogenerated chemiluminescence; QD NCs, quantum dot nanoclusters; VEGF, Vascular Endothelial Growth Factor; CPNTs, carboxylated polypyrrole nanotubes; FET, field-effect transistor; QCM, quartz crystal microbalance; apt-MBs, conjugated magnetic beads; QD, quantum dot; n.s., not specified.

\subsection{Aptasensors for Detection of Microorganisms and Viruses}

Detection, identification and quantification of microbial pathogens are crucial for public health protection. Similarly, identification of virally infected cells is essential for the study of the mechanism 
of viral diagnosis. Virus-infected cells display certain viral proteins, which are detected using probes for the detection of infection. Up to date, the ability to design probes for specific viral targets on the host cell surface is very limited. Several aptasensors have been developed to detect microorganisms and viral proteins. One representative example of HIV-1 Tat aptamers developed for detection is discussed in the following part. In addition, Table 3 lists examples of aptasensors for detection of microorganisms and viruses.

Table 3. Examples of application of aptasensors for detection of microorganisms and viruses.

\begin{tabular}{|c|c|c|c|c|c|}
\hline $\begin{array}{l}\text { Microbial and } \\
\text { viral targets }\end{array}$ & Aptamer & Detection type & $\begin{array}{c}\text { Signal } \\
\text { transduction }\end{array}$ & $\begin{array}{c}\text { Linear range/ } \\
\text { LOD }\end{array}$ & Reference \\
\hline $\begin{array}{l}\text { Bacillus } \\
\text { thuringiensis }\end{array}$ & DNA & $\begin{array}{c}\text { Aptamer-functionalized } \\
\text { QDs }\end{array}$ & Fluorescence & $\begin{array}{c}\text { n.s./ } \\
1,000 \mathrm{CFU} / \mathrm{mL}\end{array}$ & $\begin{array}{c}\text { Ikanovic et al. } \\
\text { (2007) [49] }\end{array}$ \\
\hline E. coli $\mathrm{DH} 5 \mathrm{a}$ & DNA & $\begin{array}{l}\text { Aptamer-functionalized } \\
\text { SWNT-FET arrays }\end{array}$ & Fluorescence & $\begin{array}{l}\text { n.s./ } \\
\text { n.s. }\end{array}$ & $\begin{array}{c}\text { So et al. } \\
\text { (2008) [50] }\end{array}$ \\
\hline HIV-1 Tat & RNA biotinylated & $\begin{array}{l}\text { A QCM -based and an } \\
\text { SPR-based biosensor }\end{array}$ & $\begin{array}{l}\text { QCM } \\
\text { SPR }\end{array}$ & $\begin{array}{c}\text { QCM (0-1.2 ppm) } \\
\operatorname{SPR}(0-2.5 \mathrm{ppm}) / \\
\text { QCM }(0.25 \mathrm{ppm})\end{array}$ & $\begin{array}{c}\text { Tombelli et al. } \\
\text { (2005) [51] }\end{array}$ \\
\hline $\mathrm{HCV}$ core antigen & RNA & Chip-based detection & Fluorescence & $\begin{array}{l}\text { n.s./ } \\
\text { n.s. }\end{array}$ & $\begin{array}{l}\text { Lee } \text { et al. } \\
(2007)[52]\end{array}$ \\
\hline Prion & RNA & 3-dimensional analysis & Fluorescence & $\begin{array}{l}\text { n.s./ } \\
\text { n.s. }\end{array}$ & $\begin{array}{c}\text { Mashima et al. } \\
\text { (2009) [53] }\end{array}$ \\
\hline
\end{tabular}

Abbreviations: QD, quantum dots; CFU, colony forming units; SWNT-FET, single-walled carbon nanotube field-effect transistor; QCM, quartz crystal microbalance; SPR, surface plasmon resonance; n.s., not specified.

Microgravimetric methods on piezoelectric quartz crystals are based on the change of the oscillation frequency of the crystal upon mass change at its surface owing to receptor-target binding (QCM). Then, this change of oscillation frequency is the signal that is detected. With this method, a label-free detection of the target is possible. Tombelli et al. [51] developed an aptasensor platform to detect HIV-1 Tat protein by immobilizing an RNA aptamer on a piezoelectric quartz crystal. The QCM-based aptasensor has also been compared with the corresponding SPR-based aptasensor. The two aptasensors were constructed using biotin-avidin linking onto the gold surface of the transducers (quartz crystals or chips) for the immobilization chemistry. Both platforms showed similar reproducibility, sensitivity and specificity. The linear range of SPR (1-2.5 ppm) was higher that of QCM (0-1.25 ppm) [51].

\section{Conculsions}

Aptamer science has now reached maturity, through its growing impact on biology and medicine. The therapeutic use of aptamers is now well established, as in December 2004 the first aptamer compound named Pegaptanib was approved for clinical use [54]. Conversely, the different fields of clinical diagnostics, when dealing with systems based on biomolecular interactions, are still under the supremacy of immunoassays but diagnostics studies are now showing that some of the limits of current clinical diagnostics can be circumvented by taking advantage of the differences between aptamers and antibodies, such as cost-effective synthesis, flexibility for signal transduction and detection [55]. The good news is that there are currently some more aptamers in clinical phase $2 / 3$ trials, such as factor IXa 
(FIXa), Von Willebrand factor (Vwf). However, the potential values of those aptamers for clinical diagnosis have not been fully investigated. Up to now, there is still no good answers to the question why aptamers have not yet penetrated into the clinical laboratory [56] and only a few aptasensors for clinical diagnostics were described [56,57]. As long as more aptamers will be developed and specified, the more aptasensors promise to play an important role in the future development of diagnostic methods.

\section{References}

1. Lazcka, O.; del Campo, F.J.; Munoz, F.X. Pathogen detection: A perspective of traditional methods and biosensors. Biosens. Bioelectron. 2007, 22, 1205-1217.

2. Newman, J.D.; Tigwell, L.J.; Turner, A.P.F.; Warner, P.J. Biosensors-A Clearer View; Cranfield University Publication: Cranfield, UK, 2004.

3. Tothill, I.E. Biosensors for cancer markers diagnosis. Semin. Cell Dev. Biol. 2009, 20, 55-62.

4. Wilson, D.S.; Szostak, J.W. In vitro selection of functional nucleic acids. Annu. Rev. Biochem. 1999, 68, 611-647.

5. Shamah, S.M.; Healy, J.M.; Cload, S.T. Complex target SELEX. Acc. Chem. Res. 2008, 41, $130-138$.

6. O’Sullivan, C.K. Aptasensors - The future of biosensing. Anal. Bioanal. Chem. 2002, 372, 44-48.

7. Wang, Z.; Wilkop, T.; Xu, D.; Dong, Y.; Ma, G.; Cheng, Q. Surface plasmon resonance imaging for affinity analysis of aptamer-protein interactions with PDMS microfluidic chips. Anal. Bioanal. Chem. 2007, 389, 819-825.

8. So, H.M.; Won, K.; Kim, Y.H.; Kim, B.K.; Ryu, B.H.; Na, P.S.; Kim, H.; Lee, J.O. Single-walled carbon nanotube biosensors using aptamers as molecular recognition elements. J. Am. Chem. Soc. 2005, 127, 11906-11907.

9. Polsky, R.; Gill, R.; Kaganovsky, L.; Willner, I. Nucleic acid-functionalized Pt nanoparticles: Catalytic labels for the amplified electrochemical detection of biomolecules. Anal. Chem. 2006, $78,2268-2271$.

10. Zayats, M.; Huang, Y.; Gill, R.; Ma, C.A.; Willner, I. Label-free and reagentless aptamer-based sensors for small molecules. J. Am. Chem. Soc. 2006, 128, 13666-13667.

11. Phillips, J.A.; Xu, Y.; Xia, Z.; Fan, Z.H.; Tan, W. Enrichment of cancer cells using aptamers immobilized on a microfluidic channel. Anal. Chem. 2009, 81, 1033-1039.

12. Balamurugan, S.; Obubuafo, A.; Soper, S.A.; Spivak, D.A. Surface immobilization methods for aptamer diagnostic applications. Anal. Bioanal. Chem. 2008, 390, 1009-1021.

13. Jayasena, S.D. Aptamers: An emerging class of molecules that rival antibodies in diagnostics. Clin. Chem. 1999, 45, 1628-1650.

14. Ulrich, H.; Wrenger, C. Disease-specific biomarker discovery by aptamers. Cytometry A 2009, 75, 727-733.

15. Ostatna, V.; Vaisocherova, H.; Homola, J.; Hianik, T. Effect of the immobilisation of DNA aptamers on the detection of thrombin by means of surface plasmon resonance. Anal. Bioanal. Chem. 2008, 391, 1861-1869.

16. Willner, I.; Zayats, M. Electronic aptamer-based sensors. Angew. Chem. Int. Ed. Engl. 2007, 46, 6408-6418. 
17. Rupcich, N.; Nutiu, R.; Li, Y.; Brennan, J.D. Entrapment of fluorescent signaling DNA aptamers in sol-gel-derived silica. Anal. Chem. 2005, 77, 4300-4307.

18. Rankin, C.J.; Fuller, E.N.; Hamor, K.H.; Gabarra, S.A.; Shields, T.P. A simple fluorescent biosensor for theophylline based on its RNA aptamer. Nucleos. Nucleot. Nucleic Acids 2006, 25, $1407-1424$.

19. Rupcich, N.; Nutiu, R.; Li, Y.; Brennan, J.D. Solid-phase enzyme activity assay utilizing an entrapped fluorescence-signaling DNA aptamer. Angew. Chem. Int. Ed. Engl. 2006, 45, 3295-3299.

20. Wang, X.; Zhou, J.; Yun, W.; Xiao, S.; Chang, Z.; He, P.; Fang, Y. Detection of thrombin using electrogenerated chemiluminescence based on $\mathrm{Ru}(\mathrm{bpy})_{3}\left({ }^{2+}\right)$-doped silica nanoparticle aptasensor via target protein-induced strand displacement. Anal. Chim. Acta 2007, 598, 242-248.

21. Lee, J.O.; So, H.M.; Jeon, E.K.; Chang, H.; Won, K.; Kim, Y.H. Aptamers as molecular recognition elements for electrochemical nanobiosensors. Anal. Bioanal. Chem. 2008, 390, 1023-1032.

22. Sassolas, A.; Blum, L.J.; Leca-Bouvier, B.D. Optical detection systems using immobilized aptamers. Biosens. Bioelectron. 2011, 26, 3725-3736.

23. Shevchenko, Y.; Francis, T.J.; Blair, D.A.; Walsh, R.; DeRosa, M.C.; Albert, J. In situ biosensing with a surface plasmon resonance fiber grating aptasensor. Anal. Chem. 2011, 83, 7027-7034.

24. Tombelli, S.; Minunni, M.; Mascini, M. Analytical applications of aptamers. Biosens. Bioelectron. 2005, 20, 2424-2434.

25. Wang, Y.; Yuan, R.; Chai, Y.; Yuan, Y.; Bai, L.; Liao, Y. A multi-amplification aptasensor for highly sensitive detection of thrombin based on high-quality hollow CoPt nanoparticles decorated graphene. Biosens. Bioelectron. 2011, 30, 61-66.

26. Zhao, J.; Zhang, Y.; Li, H.; Wen, Y.; Fan, X.; Lin, F.; Tan, L.; Yao, S. Ultrasensitive electrochemical aptasensor for thrombin based on the amplification of aptamer-AuNPs-HRP conjugates. Biosens. Bioelectron. 2011, 26, 2297-2303.

27. Pu, F.; Huang, Z.; Hu, D.; Ren, J.; Wang, S.; Qu, X. Sensitive, selective and label-free protein detection using a smart polymeric transducer and aptamer/ligand system. Chem. Commun. (Camb) 2009, 47, 7357-7359.

28. Zhang, X.; Zhao, Z.; Mei, H.; Qiao, Y.; Liu, Q.; Luo, W.; Xia, T.; Fang, X. A fluorescence aptasensor based on DNA charge transport for sensitive protein detection in serum. Analyst 2011, 22, 4764-4769.

29. Liao, Y.; Yuan, R.; Chai, Y.; Zhuo, Y.; Yuan, Y.; Bai, L.; Mao, L.; Yuan, S. In situ produced ascorbic acid as coreactant for an ultrasensitive solid-state tris(2,2'-bipyridyl) ruthenium(II) electrochemiluminescence aptasensor. Biosens. Bioelectron. 2011, 26, 4815-4818.

30. Wang, J.; Lv, R.; Xu, J.; Xu, D.; Chen, H. Characterizing the interaction between aptamers and human IgE by use of surface plasmon resonance. Anal. Bioanal. Chem. 2008, 390, 1059-1065.

31. Yao, C.; Qi, Y.; Zhao, Y.; Xiang, Y.; Chen, Q.; Fu, W. Aptamer-based piezoelectric quartz crystal microbalance biosensor array for the quantification of IgE. Biosens. Bioelectron. 2009, 24, 2499-2503.

32. Huang, J.; Luo, X.; Lee, I.; Hu, Y.; Cui, X.T.; Yun, M. Rapid real-time electrochemical detection of proteins using single conducting polymer nanowire-based microfluidic aptasensor. Biosens. Bioelectron. 2011, 30, 306-309. 
33. Tran, D.T.; Vermeeren, V.; Grieten, L.; Wenmackers, S.; Wagner, P.; Pollet, J.; Janssen, K.P.; Michiels, L.; Lammertyn, J. Nanocrystalline diamond impedimetric aptasensor for the label-free detection of human IgE. Biosens. Bioelectron. 2011, 26, 2987-2993.

34. Lee, S.J.; Youn, B.S.; Park, J.W.; Niazi, J.H.; Kim, Y.S.; Gu, M.B. ssDNA aptamer-based surface plasmon resonance biosensor for the detection of retinol binding protein 4 for the early diagnosis of type 2 diabetes. Anal. Chem. 2008, 80, 2867-2873.

35. Bini, A.; Centi, S.; Tombelli, S.; Minunni, M.; Mascini, M. Development of an optical RNA-based aptasensor for C-reactive protein. Anal. Bioanal. Chem. 2008, 390, 1077-1086.

36. Pultar, J.; Sauer, U.; Domnanich, P.; Preininger, C. Aptamer-antibody on-chip sandwich immunoassay for detection of CRP in spiked serum. Biosens. Bioelectron. 2009, 24, 1456-1461.

37. Mao, L.; Yuan, R.; Chai, Y.; Zhuo, Y.; Xiang, Y. Signal-enhancer molecules encapsulated liposome as a valuable sensing and amplification platform combining the aptasensor for ultrasensitive ECL immunoassay. Biosens. Bioelectron. 2011, 26, 4204-4208.

38. Liu, Y.; Tuleouva, N.; Ramanculov, E.; Revzin, A. Aptamer-based electrochemical biosensor for interferon gamma detection. Anal. Chem. 2010, 82, 8131-8136.

39. Feng, L.; Chen, Y.; Ren, J.; Qu, X. A graphene functionalized electrochemical aptasensor for selective label-free detection of cancer cells. Biomaterials 2011, 32, 2930-2937.

40. Chai, Y.; Tian, D.; Gu, J.; Cui, H. A novel electrochemiluminescence aptasensor for protein based on a sensitive N-(aminobutyl)-N-ethylisoluminol-functionalized gold nanoprobe. Analyst 2011, 136, 3244-3251.

41. Jie, G.; Wang, L.; Yuan, J.; Zhang, S. Versatile electrochemiluminescence assays for cancer cells based on dendrimer/CdSe-ZnS-quantum dot nanoclusters. Anal. Chem. 2011, 83, 3873-3880.

42. Chen, X.; Estevez, M.C.; Zhu, Z.; Huang, Y.F.; Chen, Y.; Wang, L.; Tan, W. Using aptamer-conjugated fluorescence resonance energy transfer nanoparticles for multiplexed cancer cell monitoring. Anal. Chem. 2009, 81, 7009-7014.

43. Hun, X.; Chen, H.; Wang, W. A electrogenerated chemiluminescence biosensor for Ramos cancer cell using DNA encapsulated $\mathrm{Ru}(\mathrm{bpy})\left({ }_{3}\right) \mathrm{Cl}_{2}(2)$ as signal probe. Biosens. Bioelectron. 2011, 26 , 3887-3893.

44. Pan, Y.; Guo, M.; Nie, Z.; Huang, Y.; Pan, C.; Zeng, K.; Zhang, Y.; Yao, S. Selective collection and detection of leukemia cells on a magnet-quartz crystal microbalance system using aptamer-conjugated magnetic beads. Biosens. Bioelectron. 2010, 25, 1609-1614.

45. Savory, N.; Abe, K.; Sode, K.; Ikebukuro, K. Selection of DNA aptamer against prostate specific antigen using a genetic algorithm and application to sensing. Biosens. Bioelectron. 2010, 26, 1386-1391.

46. Cheng, A.K.; Su, H.; Wang, Y.A.; Yu, H.Z. Aptamer-based detection of epithelial tumor marker mucin 1 with quantum dot-based fluorescence readout. Anal. Chem. 2009, 81, 6130-6139.

47. Bala, J.; Bhaskar, A.; Varshney, A.; Singh, A.K.; Dey, S.; Yadava, P. In vitro selected RNA aptamer recognizing glutathione induces ROS mediated apoptosis in the human breast cancer cell line MCF 7. RNA Biol. 2011, 8, 101-111.

48. Kwon, O.S.; Park, S.J.; Jang, J. A high-performance VEGF aptamer functionalized polypyrrole nanotube biosensor. Biomaterials 2010, 31, 4740-4747. 
49. Ikanovic, M.; Rudzinski, W.E.; Bruno, J.G.; Allman, A.; Carrillo, M.P.; Dwarakanath, S.; Bhahdigadi, S.; Rao, P.; Kiel, J.L.; Andrews, C.J. Fluorescence assay based on aptamer-quantum dot binding to Bacillus thuringiensis spores. J. Fluoresc. 2007, 17, 193-199.

50. So, H.M.; Park, D.W.; Jeon, E.K.; Kim, Y.H.; Kim, B.S.; Lee, C.K.; Choi, S.Y.; Kim, S.C.; Chang, H.; Lee, J.O. Detection and titer estimation of Escherichia coli using aptamer-functionalized single-walled carbon-nanotube field-effect transistors. Small 2008, 4, 197-201.

51. Tombelli, S.; Minunni, M.; Luzi, E.; Mascini, M. Aptamer-based biosensors for the detection of HIV-1 Tat protein. Bioelectrochemistry 2005, 67, 135-141.

52. Lee, S.; Kim, Y.S.; Jo, M.; Jin, M.; Lee, D.K.; Kim, S. Chip-based detection of hepatitis C virus using RNA aptamers that specifically bind to $\mathrm{HCV}$ core antigen. Biochem. Biophys. Res. Commun. 2007, 358, 47-52.

53. Mashima, T.; Matsugami, A.; Nishikawa, F.; Nishikawa, S.; Katahira, M. Unique quadruplex structure and interaction of an RNA aptamer against bovine prion protein. Nucleic Acids Res. 2009, 37, 6249-6258.

54. Gragoudas, E.S.; Adamis, A.P.; Cunningham, E.T., Jr.; Feinsod, M.; Guyer, D.R. Pegaptanib for neovascular age-related macular degeneration. N. Engl. J. Med. 2004, 351, 2805-2816.

55. Liu, J.; Cao, Z.; Lu, Y. Functional nucleic acid sensors. Chem. Rev. 2009, 109, 1948-1998.

56. Baird, G.S. Where are all the aptamers? Am. J. Clin. Pathol. 2010, 134, 529-531.

57. Zhang, P.; Zhao, N.; Zeng, Z.; Chang, C.C.; Zu, Y. Combination of an aptamer probe to CD4 and antibodies for multicolored cell phenotyping. Am. J. Clin. Pathol. 2010, 134, 586-593.

(C) 2012 by the authors; licensee MDPI, Basel, Switzerland. This article is an open access article distributed under the terms and conditions of the Creative Commons Attribution license (http://creativecommons.org/licenses/by/3.0/). 